DIVAN, Gabriel Antinolfi. Revisitando a esquerda punitiva: relações sociais, poder e agenda atual da criminologia crítica. Revista Eletrônica Direito e Política, Programa de Pós-Graduação Stricto Sensu em Ciência Jurídica da UNIVALI, Itajaí, v.14, n.1, 10 quadrimestre de 2019. Disponível em: www.univali.br/direitoepolitica - ISSN 1980-7791

\title{
REVISITANDO A ESQUERDA PUNITIVA: RELAÇÕES SOCIAIS, PODER E AGENDA ATUAL DA CRIMINOLOGIA CRÍTICA ${ }^{1}$
}

\author{
REVISITING THE PUNITIVE LEFT: SOCIAL RELATIONS, POWER AND THE \\ CURRENT AGENDA OF CRITICAL CRIMINOLOGY
}

Gabriel Antinolfi Divan²

\begin{abstract}
RESUMO
O presente artigo propõe uma série de revisões conceituais do arcabouço teórico e do discurso político-criminal que costuma se aglutinar em torno do termo esquerda punitiva. Utilizando uma leitura dialética dos padrões ligados a esse conceito, e revisitando as premissas do trabalho mais influente escrito no país sobre a temática após duas décadas de sua publicação (" $A$ esquerda punitiva", de Maria Lúcia Karam), o artigo procura rever sob o prisma de uma visão crítica os próprios elementos assentidos da crítica criminológica nessa quadra histórica. A conclusão é a de que enquanto uma série de premissas teóricas sobre a temática se mantém legítimas desde uma visão teórica calcada em predicados da segunda metade do século $X X$, outras necessariamente clamam por revisão quanto a seu teor político-criminal atual.
\end{abstract}

PALAVRAS-CHAVE: Criminologia Crítica; Esquerda Punitiva; Política Criminal; Sistema Jurídico-penal.

\section{ABSTRACT}

The present paper proposes a series of conceptual revisions of the theoretical framework and of the political-criminal discourse that usually coalesce around the punitive left term. Using a dialectical reading of the patterns linked to this concept, and revisiting the premises of the most influential work written in the country on the subject after two decades of its publication ("The Punitive Left" by Maria Lúcia Karam), the paper seeks to review under the prism of a critical vision the very elements of the criminological critique in this historical block. The conclusion is that while a series of theoretical premises on the subject remain legitimate from a

\footnotetext{
1 O presente artigo traz algumas conclusões parciais das investigações conduzidas no Projeto de Pesquisa "Estado de direito, sistemas de justiça e crítica: horizontes de uma 'nova política' junto ao Grupo de Pesquisa Dimensões do Poder e Relações Sociais, vinculado ao PPG/Direito - Mestrado em Direito da Universidade de Passo Fundo - RS.

2 Doutor em Ciências Criminais (PUCRS). Professor do PPG/Direito - Mestrado em Direito da Universidade de Passo Fundo (UPF-RS). Advogado. divan.gabriel@gmail.com
} 
DIVAN, Gabriel Antinolfi. Revisitando a esquerda punitiva: relações sociais, poder e agenda atual da criminologia crítica. Revista Eletrônica Direito e Política, Programa de Pós-Graduação Stricto Sensu em Ciência Jurídica da UNIVALI, Itajaí, v.14, n.1, $1^{\circ}$ quadrimestre de 2019. Disponível em: www.univali.br/direitoepolitica - ISSN 1980-7791

theoretical perspective based on thoughts of the second half of the twentieth century, others necessarily call for a revision as to their current political-criminal content.

KEYWORDS: Criminal legal system; Criminal Policy; Critical Criminology; Punitive Left

\section{INTRODUÇÃO}

A discussão que ora se propõe se presta a várias sendas de problematização no campo da criminologia. Como texto e/ou estudo criminológico por excelência, destaca alguns elementos diuturnamente reprisados, porém necessariamente ainda atuais e relevantes, do estudo pautado em uma criminologia essencialmente crítica em relação ao establishment teórico do direito criminal (em sentido amplo) e ao poder político-punitivo que demanda controle e fiscalização constantes.

Porém, é no campo político-criminal (ou mesmo ideológico) que se gostaria de incitar a discussão de fundo daqui derivada, e sobre os fundamentos - teóricos, jurídicos, políticos e culturais - de uma efetiva criminologia crítica que se gostaria de elucubrar com maior ênfase. Imagina-se, aqui, o predicado crítico da criminologia como tal a partir de uma crítica que, se não pode jamais servir para legitimar e simplesmente arquivar ocasional e aleatoriamente todas as vicissitudes do sistema penal e seu funcionamento normal (sem pretender inclusive classificar essas vicissitudes como 'anomalia'), deve também ser crítica no aspecto do desequilíbrio estrutural de sua atuação.

Ou seja: há (ou pode haver) dois momentos ou patamares da crítica - aquele que aponta para a diligente e incessante denúncia das deslegitimações do poder punitivo, sobretudo na margem - nos contornos em que propunha Zaffaroni ${ }^{3}$ - e aquele que (sem negar ou sobrepujar o anterior de maneira alguma), identifica em termos realistas a atualidade do abuso do poder punitivo e um outro tipo de mazela, decorrente do desnível social de sua aplicação.

\footnotetext{
3 ZAFFARONI, Eugenio Raúl. Em busca das penas perdidas: A perda de legitimidade do sistema penal. 4a edição. Tradução de Vania Romano Pedrosa. Rio de Janeiro: Revan, 1999, especialmente p. 11-44.
} 
DIVAN, Gabriel Antinolfi. Revisitando a esquerda punitiva: relações sociais, poder e agenda atual da criminologia crítica. Revista Eletrônica Direito e Política, Programa de Pós-Graduação Stricto Sensu em Ciência Jurídica da UNIVALI, Itajaí, v.14, n.1, 10 quadrimestre de 2019. Disponível em: www.univali.br/direitoepolitica - ISSN 1980-7791

Assume-se aqui uma postura demasiado pessimista em relação à possibilidade de militar por uma almejada abolição do sistema penal como um todo, e, dentro dela, rejeita a ideia de que um telos abolicionista passando por uma assunção minimalista não possam se coadunar com a constatação prática de que o sistema (ainda) existe e (segue) operando. Assim, é preciso um discurso tópico também que dê conta desse momento, paralelamente à luta de maior fundo. Embora se consiga concordar com boa parte da gama de conhecimentos críticos que, amalgamadas, tendem ao discurso de deslegitimação absoluta dos aparelhos punitivos, afina-se o pensamento com certas conclusões oriundas tangencialmente de correntes criminológicas realistas que partiam, entre outras coisas, da premissa de que não se pode trabalhar com a questão do crime e seu alusivo combate como se fossem inteiramente compostos de valores inventados ou necessariamente incutidos - como para Anitua ${ }^{4}$. Ou na prescrição de Young ${ }^{5}$, criticando o idealismo de esquerda: de pouco ou nada adianta a ilusão de que um crime cotidiano (um assalto/roubo na rua, por exemplo) é inteira e exclusivamente fruto de construções simbólicas e/ou do próprio uso cíclico desse ocorrido para incutir pânico moral sem uma teoria que dê conta do fato de que ele é, sim, uma situação social problemática (em boa parte das ocasiões, ao menos) e, sim, demanda algum tipo de estratégia para enfrenta-la, compreendê-la, evita-la ou apaziguá-la de alguma maneira.

Mais: não se pode simplesmente negacear a vitimização global de uma classe menos favorecida pela atuação da criminalidade das classes favorecidas e abarcar tudo em um discurso que visa a abolição como se até (quiçá) o emergir dessa (nova) realidade, tivéssemos que, binariamente, nos contentar em simular que a atuação penal distorcida também não tem efeitos sociais maléficos. É preciso, ainda conforme Young ${ }^{6}$ já alertou, "(...) navegar entre os dois polos", sem

\footnotetext{
${ }^{4}$ ANITUA, Gabriel Ignácio. Historias de los pensamientos criminilógicos. Buenos Aires: Del Porto, 2005, p. 445.

5 YOUNG, Jock. El fracasso de la criminologia: la necesidad de un realismo radical In HULSMAN, Louk; RECASENS I BRUNET, Amadeu; VAN SWAANINGEN, Rene; BERGALLI, Roberto; ZAFFARONI, Eugenio R.; CHRISTIE, Nils, YOUNG, Jock. Criminología crítica y control social: El poder punitivo del Estado. Tradução de Ramiro Sagarduy. Rosário: Editorial Juris, 1993, p. 30.
}

6 YOUNG, Jock. El fracasso de la criminologia: la necesidad de un realismo radical, p. 32. 
DIVAN, Gabriel Antinolfi. Revisitando a esquerda punitiva: relações sociais, poder e agenda atual da criminologia crítica. Revista Eletrônica Direito e Política, Programa de Pós-Graduação Stricto Sensu em Ciência Jurídica da UNIVALI, Itajaí, v.14, n.1, 10 quadrimestre de 2019. Disponível em: www.univali.br/direitoepolitica - ISSN 1980-7791

sucumbir ao pânico (promovido pelo discurso punitivo-legitimador) nem sofismar negando o caráter pernicioso que pode ter o crime, em si, de forma geral.

A partir de premissas como as de Foucault ${ }^{7}$ discutindo os caminhos para uma real e genuína sublevação dos aparelhos e estamentos jurídico-políticos burgueses (ou, mais propriamente, as contradições de um pensamento simplório a esse respeito) e, especialmente no Brasil, de uma impactante e arguta manifestação de Maria Lúcia Karam ${ }^{8}$ apontando as falácias de uma possível estratégia de uso político das estruturas punitivas do estado para a correção de desigualdades sociais, se convencionou a batizar e reagrupar uma série de posicionamentos e discursos como parte da esfera de uma dita esquerda punitiva: seriam, pois, os discursos que procurariam formas e condicionamentos teóricos para que a estrutura jurídicopenal vigente pudesse ser manejada em sentido contrário daquele visivelmente seletivo (e sobretudo, classista) que comumente ganha a aplicação cotidiana e que justamente (por esse fator) é um dos alvos dos teóricos crítico.

Ao tempo em que se contam já duas décadas do impactante ensaio referido de autoria de Karam (e sua merecida e gigantesca influência no debate criminológicocrítico brasileiro desde então), parece importante revisitar suas ideias para a confirmação da solidez de vários dos posicionamentos ali elencados. E também para a, ousadia, de alguns questionamentos e revisões - não sem ter em consciência de que alguns cenários políticos de outrora e sua análise não poderiam abarcar realidades posteriores. Um texto que expõe e pauta de maneira tão forte - ideário da crítica criminológica brasileira merece ser destinatário de tal homenagem (ainda que com doses de discordância) na quadra de vinte anos corridos de sua publicação.

É preciso explicitar que não se pretende uma espécie de retomada (falsamente) dialética de contrapontos infindáveis com muitas das premissas iniciais desse ensaio (bem como textos igualmente relevantes de outros autores exemplificados)

\footnotetext{
7 FOUCAULT, Michel. Microfísica do poder. 20. ed. Tradução de Roberto Machado. Rio de Janeiro: Graal, 2004, especialmente p. 39-68.

8 KARAM, Maria Lúcia. A esquerda punitiva. Discursos Sediciosos: Crime, Direito e Sociedade. Rio de Janeiro: Relume Dumará/ICC. Ano 1, volume 1, p. 79-92, $1^{\circ}$ semestre/1996.
} 
DIVAN, Gabriel Antinolfi. Revisitando a esquerda punitiva: relações sociais, poder e agenda atual da criminologia crítica. Revista Eletrônica Direito e Política, Programa de Pós-Graduação Stricto Sensu em Ciência Jurídica da UNIVALI, Itajaí, v.14, n.1, 10 quadrimestre de 2019. Disponível em: www.univali.br/direitoepolitica - ISSN 1980-7791

enquanto pedra de toque. Um bom número de seus argumentos oferecidos, aliás, é simplesmente incontornável e ajusta o raciocínio para a inegável premissa teórica - e compromisso político - de que qualquer legado de confiança cega e de crédito incauto ao sistema jurídico-penal estatal e qualquer legitimação enquanto profissão de fé ao poder punitivo é retrocesso teórico e borda para sua consequente expansão. Expansão essa, quase sempre de fundo notadamente malévolo no seio social - crenças ou créditos que estimulam o barômetro da apropriação burocrática da verticalidade cogente em relação à horizontalidade comunitária (como já pontuaram Zaffaroni, Alagia e Slokar ${ }^{9}$ ), e sempre em prol da manutenção dos graus de poder onde eles costumeiramente se encontram.

De fato, a premissa se baseia em um considerável espectro de discursos críticos de cunho social e político de viés passível de ser associado como left-wingers (como, por exemplo, os discursos feminista, ecologista e de defesa pacifista e/ou de direitos humanos - lembrando que a caracterização de esquerdas quanto a esses grupos não é tão fácil, tal sugere Larrauri ${ }^{10}$ ), que, mais fortemente a partir da eclosão da crítica contracultural dos anos 60 e de seus reflexos nas décadas posteriores, passou a considerar a hipótese de, nas palavras de Karam ${ }^{11}$, reivindicar a " (...) extensão da reação punitiva a condutas tradicionalmente imunes à intervenção do sistema penal".

Assim sendo, uma espécie de abalo sísmico ideológico se delineia: grupos defensores de valores quase sempre vitimados pelos estamentos mais aflitivos do sistema penal no solapar de direitos fundamentais, passam agora a querer usufruir da máquina ao invés de seguir reconhecendo-a como essencialmente opressora e abandonável.

Parece francamente impossível de negacear a visão similar de Foucault ${ }^{12}$, que alerta para uma contradição em termos relativa à democracia real ou à afamada

\footnotetext{
9 ZAFFARONI, Eugenio Raúl; ALAGIA, Alejandro; SLOKAR, Alejandro. Derecho penal: Parte general. $2^{a}$ edição. Buenos Aires: EDIAR, 2002, p. 230.

10 LARRAURI, Elena. La Herencia de la Criminología Crítica. Madrid: Siglo Veintiuno de España, 2000, p. 192.

11 KARAM, Maria Lúcia. A esquerda punitiva, p. 79.

12 FOUCAULT, Michel. Microfísica do Poder, p. 42-47.
} 
DIVAN, Gabriel Antinolfi. Revisitando a esquerda punitiva: relações sociais, poder e agenda atual da criminologia crítica. Revista Eletrônica Direito e Política, Programa de Pós-Graduação Stricto Sensu em Ciência Jurídica da UNIVALI, Itajaí, v.14, n.1, $1^{\circ}$ quadrimestre de 2019. Disponível em: www.univali.br/direitoepolitica - ISSN 1980-7791

justiça popular ser vivificada por uma estrutura que interdita seus preceitos desde o (literalmente) formato/disposição de seus atores e ritos. Tanto quanto impossível o é negacear quanto ao alerta dado por Karam ${ }^{13}$, de que, inclusive

[...] apropriando-se de um generalizado e inconsequente clamor contra a impunidade, estes amplos setores da esquerda foram tomados por um desenfreado furor persecutório, centralizando seu discurso em um histérico e irracional combate à corrupção, não só esquecidos das lições da história a demonstrar que esse discurso tradicionalmente monopolizado pela direita já funcionara muitas vezes como fator de legitimação das forças mais reacionárias

Logicamente, se procurará seguir em bases de resistência que não abrem mão de fazer uma crítica frontal a um conjunto punitivo que ganha guarida e apoio no sistema jurídico e no edifício legislativo para, a todo instante, excepcionar lhes e, assim, excepcionar (em última análise) a si mesmo em prol de interesses fluidos. Interesses, aliás, que terminam por ocasionar as consequências sociais mais diversas e nefastas - e desaguar onde desrespeitos mais vis e binários aos direitos humanos são peças de uma estranha accountability festejada.

No entanto, em meio a um profundo questionamento de ordem filosófica e em meio a uma plataforma teórica que se pretende de resistência, cabe questionar, não sobre a ideia básica de (im)possibilidades de mero uso da maquinaria penal, mas sobre outra questão que, com Pinto Neto ${ }^{14}$, ganha coro nesse momento:

Longe de nós a elegia ao punitivismo rasteiro, a demagogia do sacrifício de bodes expiatórios, o aplauso ao arcaísmo e à violência do sistema penal. Longe de nós a crença em messianismos social-democratas de intervenção estatal que irão redimir a população pobre por meio da implementação de direitos sociais, justificando a criminalização. Longe de nós a relegitimação do sistema punitivo que, atualmente, é genocídio em ato - basta dizer isso para o entender. No

\footnotetext{
13 KARAM, Maria Lúcia. A esquerda punitiva, p. 80.

14 PINTO NETO, Moysés da Fontoura. Em defesa da esquerda punitiva. Rastros, n. 1. Florianópolis, out. 2012, p. 4.
} 
DIVAN, Gabriel Antinolfi. Revisitando a esquerda punitiva: relações sociais, poder e agenda atual da criminologia crítica. Revista Eletrônica Direito e Política, Programa de Pós-Graduação Stricto Sensu em Ciência Jurídica da UNIVALI, Itajaí, v.14, n.1, $1^{\circ}$ quadrimestre de 2019. Disponível em: www.univali.br/direitoepolitica - ISSN 1980-7791

entanto, repetimos a pergunta: a que funções reais tem servido o discurso contrário à esquerda punitiva?

Esse simples questionamento, rico, no entanto, de possibilidades, irá nortear essa singela discussão sobre, principalmente, como já fora exposto, um debate sobre a epistemologia de uma criminologia que se pretenda crítica.

A seguir, pretender-se-á expor um balanço de pilares argumentativos fundamentais do texto de Karam seguidos de respectivos comentários alusivos tanto aos temas de fundo pela autora trabalhados quanto à epistemologia criminológica deles decorrente.

Lembrando que procurar-se-á, sempre, discernir entre a esquerda punitiva pejorativamente assentida - merecedora das críticas certeiras disparadas por Karam - de posicionamentos que, por se verificarem de inspiração realista e de bases também calcadas em uma criminologia dita radical (como há muito já referia Cirino dos Santos ${ }^{15}$ ), reclamam por uma crítica criminológica que também ataque o desequilíbrio punitivo em relação às classes mais poderosas como sintoma de distorção, e não de uma incidência penal a menos a ser festejada.

Parece que, nessa linha, se pode guiar por duas hipóteses prévias para a crítica: I- a de que o simples uso dos argumentos de Karam (como baluarte descontextualizado sempre oponível em debates sobre a temática) acarreta em incongruências e, II- a de que as premissas do texto costumam vir à baila, por vezes, muito mais para neutralizar possíveis rediscussões e revisões de posicionamentos do que para fincar uma base ideológica de efetiva resistência.

Como já se explicitou supra, algumas premissas trazidas pelo texto seminal de Karam são pontos de apoio argumentativo para toda uma visualização no campo da criminologia crítica, historicamente ligada ao pensamento político de esquerda

15 CIRINO DOS SANTOS, Juarez. A criminologia radical. 2a edição. Rio de Janeiro: Lumen Juris/ICPC, 2006, p. 86-91 
DIVAN, Gabriel Antinolfi. Revisitando a esquerda punitiva: relações sociais, poder e agenda atual da criminologia crítica. Revista Eletrônica Direito e Política, Programa de Pós-Graduação Stricto Sensu em Ciência Jurídica da UNIVALI, Itajaí, v.14, n.1, $1^{\circ}$ quadrimestre de 2019. Disponível em: www.univali.br/direitoepolitica - ISSN 1980-7791

em suas várias correntes e acepções ${ }^{16}$. E, diante da merecida relevância do pensamento da autora no campo jurídico-penal e criminológico brasileiro, pauta necessária de discussão acadêmica e política.

Salutar lembrar que não se corre, com a presente digressão, nenhum risco de que as opiniões sejam ora invertidas e desconectadas de suas premissas para fortalecer um discurso punitivista rasteiro: a própria base de pensamento oriunda dos autores e autoras aqui trazidos ostenta de forma inconteste a marca do pensamento crítico e em que pese as divergências (algumas de ramificações teóricas, outras de contextos e premissas ideológicas), trata-se de discutir dentre e com o pensamento (criminológico) crítico e não ofertar-Ihe um ataque ou questionamento exterior.

A partir de agora, em uma seleção cuidadosa (mas que não pode fugir do rótulo de arbitrária, como em certo nível o é toda e qualquer seleção), será exibida uma série de tópicos que, presumidamente, compõem a estrutura basilar de insights e constatações do texto-base, para em seguida serem alvo das anunciadas ponderações.

\section{A ESQUERDA PUNITIVA ENQUANTO INGENUIDADE POLÍTICA}

Quando Karam aduz ${ }^{17}$ que o sistema penal em si é uma característica e um mecanismo próprio do capitalismo e milita em favor das várias facetas de seu próprio status quo, não há nenhuma inverdade. É impossível torcer a constatação básica, dado que os objetivos reais ou encobertos (pelo discurso oficial da neutralidade técnica) do direito e de todo o sistema jurídico-penal funcionam no esquema da lógica do modo capitalista de produção e trabalham com uma

\footnotetext{
${ }^{16}$ Cf. DIVAN, Gabriel Antinolfi. Qual nossa única reivindicação? Representatividade e cruzamentos políticos para a construção de uma 'criminologia 2.0'. Panóptica. Vitória: FDV vol. 10, n. 2, p. 158175, Julho/Dezembro, 2015

17 KARAM, Maria Lúcia. A esquerda punitiva, p. 79.
} 
DIVAN, Gabriel Antinolfi. Revisitando a esquerda punitiva: relações sociais, poder e agenda atual da criminologia crítica. Revista Eletrônica Direito e Política, Programa de Pós-Graduação Stricto Sensu em Ciência Jurídica da UNIVALI, Itajaí, v.14, n.1, $1^{\circ}$ quadrimestre de 2019. Disponível em: www.univali.br/direitoepolitica - ISSN 1980-7791

modulação planejada de repressão-permissividade que varia conforme o quanto parte da classe hegemônica ou não é a clientela (como leciona Cirino dos Santos ${ }^{18}$ )

No entanto, a autora sustenta que um verdadeiro - ou mais genuíno - caminho da crítica passaria pelo direcionamento das baterias da episteme criminológica para mirar em uma promessa futura de abolicionismo. Que a crítica abolicionista é ferrenha e politicamente passível de implemento em muitas de suas premissas extintivas, não parece haver dúvida (ao contrário do que especula Ferrajoli ${ }^{19}$ refutado contundentemente por Larrauri ${ }^{20}$ ). Mas o panorama não parece muito alvissareiro, por hora, para possibilitar um vislumbre de taxatividade abolicionista que não se traduza em um plano de (longa) transição minimizadora e só. Até porque enquanto não sepultadas uma série de contradições atinentes à própria lógica do capital, o problema atrelado e seus sistemas e maquinações contíguas igualmente permanecerão de uma forma ou outra.

Alguns aspetos não têm qualquer possibilidade de guarida político-legislativa atual e exigiriam um debate sobretudo sociocultural em um imenso prazo.

De se considerar também, ainda que formalmente, a existência de mandados criminalizantes de ordem e dignidade constitucional ${ }^{21}$ que sistematicamente impediriam um abolir generalizado do sistema, embora não bloqueiem um questionar do encarceramento e da lógica prisional reinante. Parece desde logo possível delinear um resguardo da posição crítica ferrenha sem que isso signifique deixar de lidar com os problemas iminentes de uma atuação punitiva que bate à porta e está na ordem do dia.

\footnotetext{
${ }^{18}$ CIRINO DOS SANTOS, Juarez. Direito penal. Parte Geral. $2^{\text {a }}$ edição. Revista e ampliada. Rio de Janeiro: Lumen Juris/ICPC, 2007, p. 9-14.

19 FERRAJOLI, Luigi. Derecho y razón: Teoría del garantismo penal. Tradução de Perfecto Andres Ibáñez et alii. Madrid: Trotta, 1995, p. 338-340.

20 LARRAURI, Elena. Criminología crítica: abolicionismo y garantismo. Revista de Estudos Criminais. Porto Alegre: Notadez/ITECRS/PUCRS Ano V, n. 20, p. 11-28, Dezembro/2005, p. 1921.

${ }^{21}$ Cf. DOLCINI, Emilio; MARINUCCI, Giorgio. Constituição e escolha de bens jurídicos. Tradução de José de Faria Costa. Revista Portuguesa de Ciência Criminal. Lisboa: Fascículo 2. Ano 4, p. 151198, Abril/Junho, 1994.
} 
DIVAN, Gabriel Antinolfi. Revisitando a esquerda punitiva: relações sociais, poder e agenda atual da criminologia crítica. Revista Eletrônica Direito e Política, Programa de Pós-Graduação Stricto Sensu em Ciência Jurídica da UNIVALI, Itajaí, v.14, n.1, 10 quadrimestre de 2019. Disponível em: www.univali.br/direitoepolitica - ISSN 1980-7791

Se o texto da carta política é usado quando engajado em barreiras (legais e até retóricas) em favor de valores e direitos humanistas como um importante combustível crítico, não pode ser solenemente ignorado no trecho em que reconhece um revés político de criminalização abstrata ou de punição (em sentido amplo) - ainda que, conforme há muito lembrou Carvalho ${ }^{22}$, não haja constitucionalmente adoção alguma de justificativa ou fundamentalismo punitivo.

Afastar-se do curso ou telos abolicionista poderia significar uma premissa errônea e derrotista dos discursos críticos, sim, mas afastar-se de batalhas e bravatas inaplicáveis e anti-estratégicas não parece qualquer tipo de ingenuidade, senão que reclamação diante de demandas urgentes e emergenciais. Parece preferível que - ainda que se assuma o abolicionismo como fim ideológico e/ou como espécie de ideal, por hora, embotado - se procurem alternativas para solucionar as controvérsias da atualidade ao invés de militar em uma crítica autorreferente e cuja viabilidade de aplicação está sempre jogada no futuro. A parábola da utopia que ruma ao horizonte e obriga à caminhada incessante (tal voto de esperança) já é fava contada e para além da candura das imagens, sua aplicação enquanto mote criminológico-crítico já parece ter se esvaído.

Que ninguém esteja confortável com a constatação (superlativa, mas tristemente factual) do genocídio em ato que é o funcionamento cotidiano do sistema jurídicopenal é mais do que natural: premissa que se impõe. Mas não se pode crer que a única saída crítica autêntica ou legítima é um discurso que tenha o abolicionismo penal por finalidade última, como se discursos minimalistas que aceitem a convivência com algum espectro de leis punitivas (conformadas em um patamar mais exíguo, razoável e racional possível, como democraticamente se poderia sustentar) fossem necessariamente hipócritas ou exemplo de uma crítica falsária e covarde.

O afastamento da base discursiva abolicionista - ou daquela que esteia seus interditos em promessas de abolicionismos futuros - não pode ser medida única

22 CARVALHO, Salo de. Teoria Agnóstica da Pena: entre os supérfluos fins e a limitação do poder punitivo In. CARVALHO, Salo de. Crítica à Execução Penal. $2^{a}$ edição. Rio de Janeiro: Lumen Juris, 2007, p. 3-28. 
DIVAN, Gabriel Antinolfi. Revisitando a esquerda punitiva: relações sociais, poder e agenda atual da criminologia crítica. Revista Eletrônica Direito e Política, Programa de Pós-Graduação Stricto Sensu em Ciência Jurídica da UNIVALI, Itajaí, v.14, n.1, $1^{\circ}$ quadrimestre de 2019. Disponível em: www.univali.br/direitoepolitica - ISSN 1980-7791

para determinar, pura e simplesmente, o quão lúcido (ou verdadeiro) é um discurso crítico.

Seria mesmo uma ingenuidade (ou alienação) propor um rumo de epistemologia para teorias criminológicas (críticas) que considere a busca (ideal) pela deslegitimação do sistema como passível de convivência com uma necessidade de racionalização de seu uso iminente? Trata-se de uma proposta de fundo que engloba um caráter de remediar: a atuação punitiva vai perdurar ainda de modo sólido por muito tempo na atual conjuntura. Não é insensato defender que sua configuração seja o mais justa e equânime possível, uma vez que ela, por hora, tem que ser usada (ou vai ser). Ingenuidade seria desistir de criminalizar os "inatingíveis" crendo que essa descriminalização é da mesma ordem crítica dos rumos abolicionistas - ou por eles cooptável.

Não se pode aludir a todo e qualquer discurso que reconheça ou que admita a realidade do poder punitivo a pecha de padecer de "permanências positivistas, discursos morais e reducionismos", como sustenta Batista ${ }^{23}$. Curioso inclusive que a autora (outra pensadora baluarte da crítica criminológica brasileira, de igual, incontestável e merecida influência) faça alusão à ideia marxista sobre uma desintegração estatal como fim ótimo, a começar pelo enxugamento do sistema jurídico-penal: "(...) É impressionante como a esquerda esqueceu a tese do fim do Estado e trabalha a questão pelo paradigma da ordem do capital". Se fosse ideal levar a discussão ao pé da letra, poder-se-ia dizer que alguns setores da esquerda estão procurando vivificar, justamente, o momento de uso do aparelho jurídico (penal) burguês previsto por teóricos marxistas como o campo intermediário de transição socialista - mas levar-se-ia a problemática ora travada para confins aqui não pretendidos (como por exemplo, com força em aportes de Pachukanis ${ }^{24}$

\footnotetext{
${ }^{23}$ BATISTA, Vera Malaguti. Introdução crítica à criminologia brasileira. $1^{a}$ reimpressão. Rio de Janeiro: Revan, 2014, p. 86

24 PACHUKANIS, Evguiéni B. Teoria geral do direito e marxismo. $1^{a}$ edição. Tradução de Paula Vaz de Almeida. São Paulo: Boitempo, 2017, p. 78-80.
} 
DIVAN, Gabriel Antinolfi. Revisitando a esquerda punitiva: relações sociais, poder e agenda atual da criminologia crítica. Revista Eletrônica Direito e Política, Programa de Pós-Graduação Stricto Sensu em Ciência Jurídica da UNIVALI, Itajaí, v.14, n.1, $1^{\circ}$ quadrimestre de 2019. Disponível em: www.univali.br/direitoepolitica - ISSN 1980-7791

Naves ${ }^{25}$; e, sobretudo, no próprio $\operatorname{Marx}^{26}$ em sua especulação específica sobre a questão).

\section{A ESQUERDA PUNITIVA ENQUANTO ADESÃO AO PUNITIVISMO}

A ideia de que aqueles que defendem uma esquerda punitiva no sentido pernicioso e pejorativo que Karam $^{27}$ trata com propriedade, passariam inclusive a utilizar o subterfúgio outrora denunciado do depósito de crença "mítica" na magistratura pode ser verdadeiro, em relação a essa própria parcela.

Porém, é importante que se diga que não há que se associar indiscriminadamente uma cobrança de rigor equalizado (ou uma ampliação de rigor investigativo) em relação à criminalidade dourada (termo identificador do contingente costumeiramente fora da alça de mira punitivista), com todo um retrocesso processual-discursivo inquisitorial. As figuras glorificadas de investigadores, acusadores e - especialmente - magistrados, bem como o arsenal discursivo e hermenêutico canhestro que essa glorificação enseja e possibilita perante os procedimentos legais estão de fora do salão de argumentação republicana quanto mais criminológico-crítica autêntica.

Se por acaso se estiver falando exclusivamente da hipocrisia maniqueísta de uma esquerda punitiva iludida, é possível, repete-se, que a premissa seja válida. Porém é sofisma dizer que há uma legitimação de base que desfaz por terra um argumento crítico quando ele não impõe interditos de toda e qualquer ordem a toda e qualquer ação perpetrada pelo sistema. Conforme já exposto, se não parece razoável (nem situada) qualquer opinião que não parta da necessidade do binômio crítica-controle (fiscalizador) da atuação e da expansão espúria do poder punitivo, de outro modo não parece honesto (registrando-se que Karam não faz essa

\footnotetext{
${ }^{25}$ NAVES, Márcio Bilharino. Marxismo e direito: Um estudo sobre Pachukanis. Tese (Doutorado em Filosofia). Instituto de Filosofia e Ciências Humanas. Universidade Estadual de Campinas. Capinas: Unicamp, 1996, p. 115-117.

${ }^{26}$ MARX, Karl. Crítica ao Programa de Gotha. Tradução de Rubens Enderle. São Paulo, Boitempo, 2012, p. 33.

27 KARAM, Maria Lúcia. A esquerda punitiva, p. 80
} 
DIVAN, Gabriel Antinolfi. Revisitando a esquerda punitiva: relações sociais, poder e agenda atual da criminologia crítica. Revista Eletrônica Direito e Política, Programa de Pós-Graduação Stricto Sensu em Ciência Jurídica da UNIVALI, Itajaí, v.14, n.1, 10 quadrimestre de 2019. Disponível em: www.univali.br/direitoepolitica - ISSN 1980-7791

generalização e não incorre nessa simplificação) que a atividade cotidiana do sistema seja sempre balizada pela crítica irrefreável: não seria coerente defender que qualquer tipo de inação dos atores do sistema frente a integrantes desse panteão dourado de criminalidade seja o discurso adequado diante da premissa (ou vontade) de abolição de atuação também contra os membros da criminalidade das chamadas obras toscas ${ }^{28}$, clientes preferenciais do sistema.

A argumentação se perfaz em jogo de cena que - de boa índole ou não - recusase, ao fim e ao cabo, a trabalhar com a concretude da injustiça perpetrada pelo flagrante diferencial de tratamento entre classes sociais distintas.

Não parece que haja uma necessária correlação entre o questionamento ora proposto e uma obrigatória mudança de lado para que se passe indiscriminadamente a enaltecer figuras, cargos e poderes que ora justamente se criticam pelos próprios desmandos (que geram essas distorções, para mais e para menos).

Bom ressaltar igualmente que seria recomendada parcimônia aos críticos que, denunciando abusos que merecidamente merecem agravo e destaque, contudo exageram em superlativizações, apontando a todo instante categorizações como inquisição, fascismo, ou mesmo nazismo, como ferramenta retórica. As comparações hiperbólicas terminam prestando um desserviço no instante em que esvaziam totalmente conceitos importantes e historicamente assentados.

Segundo pensadores do quilate de Mathews ${ }^{29}$, uma visão realista (e nem por isso menos crítica ou menos passível de engajamento político pela esquerda) poderia ser uma resposta segura à perversidade inata de uma lógica atuarial que inclusive fracassou manifestamente em seus propósitos quando fora trazida à baila como salvaguarda explicativa. Não se pode partir de uma premissa (tal um bloqueio) que coliga necessariamente a assunção de que há (alguma, ainda que mínima)

28 ZAFFARONI, Eugenio Raúl; ALAGIA, Alejandro; SLOKAR, Alejandro. Derecho penal: Parte general, p. 10.

29 MATTHEWS, Roger. Realist Criminology. London: Palgrave Macmillan, 2014, p. 28-29. 
DIVAN, Gabriel Antinolfi. Revisitando a esquerda punitiva: relações sociais, poder e agenda atual da criminologia crítica. Revista Eletrônica Direito e Política, Programa de Pós-Graduação Stricto Sensu em Ciência Jurídica da UNIVALI, Itajaí, v.14, n.1, $1^{\circ}$ quadrimestre de 2019. Disponível em: www.univali.br/direitoepolitica - ISSN 1980-7791

tarefa para o sistema punitivo com uma total e irrestrita chancela despreocupada de filtragem, sem se ater voluntariamente ao sofisma.

Inclusive, sempre há que se levar em conta, de que não é a partir da obstaculização de considerar algum resquício de legitimidade punitiva como válido (em termos sociais) que vislumbrem uma que o debate parece ter vias de avançar politicamente com algum resultado em prol da minimização ou da abolição. 0 idealismo exagerado em relação à ausência de correspondência alardeada entre o maquinário punitivo e (qualquer) anseio social legítimo é visivelmente falacioso ${ }^{30}$.

\section{A ESQUERDA PUNITIVA ENQUANTO ADESÃO AO CLAMOR PÚBLICO}

A impunidade tida por reinante no sistema punitivo e especificamente prisional brasileiro, alardeada pelos empresários morais e por variados meios de comunicação coniventes pode ter grande parte de seu estofo calcado em manipulação geradora de pânico. Mas um certo dado de impunidade parece estatisticamente real, ao menos em se tratando de certas parcelas do contingente criminal pátrio.

É possível concluir que o sistema não é justo - se não por não distribuir interditos e abolições, mas, no caso de seu atual funcionamento cotidiano, por não distribuir equanimemente suas mazelas (e aqui não se está de forma alguma tratando dessas mazelas como quinhão ao qual se teria direito - para que se evite esgrimas retóricas absurdas). A atuação do sistema é um fato. A abolição do sistema é uma meta (ou um plano). Enquanto não se puder falar em desuso pleno da máquina punitiva, seu uso franqueado por um sem número de circunstâncias em apenas um tipo específico da camada de obras criminais não é fonte de alívio (por termos

30 DIVAN, Gabriel Antinolfi. CASTAMANN, Eduardo Tedesco. Realismo crítico, política criminal e dogmática: o papel ativo do discurso criminológico na inovação legislativa e doutrinária. Revista de Criminologias e Políticas Criminais. Maranhão: CONPEDI, volume 3, n. 2, p. 33-48, Julho/Dezembro de 2017. Disponível em: http://indexlaw.org/index.php/revistacpc/article/view/2368/pdf Acesso em 02 de Fevereiro de 2018. 
DIVAN, Gabriel Antinolfi. Revisitando a esquerda punitiva: relações sociais, poder e agenda atual da criminologia crítica. Revista Eletrônica Direito e Política, Programa de Pós-Graduação Stricto Sensu em Ciência Jurídica da UNIVALI, Itajaí, v.14, n.1, $1^{\circ}$ quadrimestre de 2019. Disponível em: www.univali.br/direitoepolitica - ISSN 1980-7791

- pelo menos quanto a alguém - menos sistema em curso). É, sim, podendo se afirmar com segurança, fonte de injustiça.

Se em relação a algum tipo de criminalidade rasa mesmo o discurso adotado pelas cortes e material jurisprudencial deixa evidente o trato diverso (por todos, a contribuição de Ferreira ${ }^{31}$ ), é em relação à criminalidade de alta patente que se verifica o trecho mais tenebroso da distorção.

Sem qualquer pecha de reacionarismo reverso ou revanchismo simplório, o foco de análise criminológica (crítica) não só pode como deve passar igualmente e ter por tarefa, em larga escala, exibir e discutir as contradições e válvulas de escape - sociais, políticas, éticas, jurídicas - que se posicionam ante a criminalização daquela parcela da população que integra o grupo dos "too big to fail" (grandes/poderosos demais para que possam errar), que, por conseguinte (em expressão jocosa em língua inglesa) se desdobram, para pesquisadores como David Schicor e Gregg Barak, em "too big to jail", ou seja, grandes/poderosos demais para que sejam presos ${ }^{32}$.

Sobram exemplos para a constatação de que tanto os países ditos desenvolvidos como aqueles ditos periféricos possuem em comum uma grossa camada de blindagem política e jurídica que faz frente à criminalização de certas esferas sociais e ofertam dificuldades estruturais ou até específicas tanto à imputação ou mesmo à investigação criminal, em relação a megacorporações, aliados do grande capital ou à esfera político-administrativa em si.

Um dos exemplos mais pontuais é a discussão que simplesmente salta para fora ou para além - dos vetores jurídico-penais em relação a gestores de bancos como o Goldman Sachs no escândalo da quebra financeira causada pelo estouro da bolha imobiliária das hipotecas nos Estados Unidos (entre 2007 e 2009). Como se sabe, a euforia de ordem especulativa em relação ao aquecido mercado imobiliário

${ }^{31}$ Cf. FERREIRA, Carolina Costa. Discursos do Sistema Penal: A seletividade no julgamento dos crimes de furto, roubo e peculato nos tribunais regionais federais do Brasil. Curitiba: Editora CRV, 2013.

32 SHICOR, David. Financial Misrepresentation and fraudulent manipulation: SEC Settlements with Wall Street Firms in the Wake of the Economic Meltdown In. BARAK, Gregg (Org.) The Routledge International Handbook of the Crimes of the Powerful. New York: Routledge, 2015, p. 282. 
DIVAN, Gabriel Antinolfi. Revisitando a esquerda punitiva: relações sociais, poder e agenda atual da criminologia crítica. Revista Eletrônica Direito e Política, Programa de Pós-Graduação Stricto Sensu em Ciência Jurídica da UNIVALI, Itajaí, v.14, n.1, 10 quadrimestre de 2019. Disponível em: www.univali.br/direitoepolitica - ISSN 1980-7791

americano gerou produtos de investimento sem qualquer lastro e concessões de linhas de crédito com avaliações de garantia e solvabilidade absolutamente questionáveis (mas que eram liberadas em prol de, ciclicamente, manter e elevar o aquecimento). O mercado atraiu multidões em busca de empréstimo para aquisição imobiliária em termos exageradamente facilitados e ilusórios (com o grande público tendo incentivo através de fiabilidades monetárias fraudulentamente atestadas), e se mostrou uma posterior armadilha com as taxas de juros que geravam novos financiamentos e novas taxas (enredando o devedor) até o súbito e (em certo aspecto) inesperado colapso total gerado pelo (óbvio) pico da inadimplência. Colapso que, se pode ser em alguma escala imputado à irresponsabilidade do público consumidor, certamente se revela enquanto "(...) misrepresentation and fraudulent manipulation of securities" ${ }^{33}$ pelas instituições financeiras.

Logicamente, a correção posterior do livre mercado financeiro que circunda o touro wallstreetiano e sua salvação que evitará o prolongamento do colapso com a falência em cadeia de muitas instituições do tipo too big (grandes demais) nos anos posteriores se dá via injeção de dinheiro público - sobre o que seria interessante uma digressão, mas não nesse momento diante dos singelos objetivos do presente trabalho.

Bem como no Brasil, o discurso da maior eficiência de um "Direito Administrativo Sancionador" sempre surge alvissareiro para tentar bloquear ou elidir imputações penais da clientela dourada e o debate alarmante - conforme mostra Schicor chega à discussão de que a irresponsabilidade aguda dos gestores do Goldman Sachs e demais especuladores no caso fora assumidamente antiética, mas inteiramente de acordo com a normalidade de Wall Street (o que, segundo o autor $^{34}$, se perfaz como exemplo de perfeito encaixe nas conhecidas Teorias criminológicas de Justificação de Sykes e Matza, onde hipotética ou mesmo

\footnotetext{
33 "Manipulação fraudulenta de valores mobiliários" (em tradução livre). SCHICOR, David. Financial Misrepresentation and fraudulent manipulation: SEC Settlements with Wall Street Firms in the Wake of the Economic Meltdown, p. 279.

34 SCHICOR, David. Financial Misrepresentation and fraudulent manipulation: SEC Settlements with Wall Street Firms in the Wake of the Economic Meltdown, p. 281.
} 
DIVAN, Gabriel Antinolfi. Revisitando a esquerda punitiva: relações sociais, poder e agenda atual da criminologia crítica. Revista Eletrônica Direito e Política, Programa de Pós-Graduação Stricto Sensu em Ciência Jurídica da UNIVALI, Itajaí, v.14, n.1, 10 quadrimestre de 2019. Disponível em: www.univali.br/direitoepolitica - ISSN 1980-7791

instintivamente, se buscam termos para normalizar, minimizar ou justificar condutas criminosas enquanto socialmente aceitáveis ou neutras).

A ideia há muito suscitada - até com finalidade de tons abolicionistas ou desencarceradores, por muitos - de um "Direito Administrativo Sancionador" substitutivo do estigmatizante reflexo penal/punitivo está sempre pronta a destrinchar no campo político qualquer possibilidade de responsabilização penal que possa ser (privilégio estranho de apenas alguns poucos) solúvel em valores monetários.

A atuação de órgãos de fiscalização estadunidense responsáveis por avaliar as movimentações financeiras (SEC - Secure Exchange Comission) pela apuração dos equívocos e fraudes no caso da quebra ocasionada pela bolha imobiliária e o resgate de somas de dinheiro com as multas e encargos de cunho sancionador vai assim tragicamente resumida por Schicor:

Following this policy, the SEC secures fines of millions of dollars from firms that made billions through allegedly wrongful practices. The settlements, which routinely include a "neither admit nor deny" clause allow the agency to receive the fines without risking an unsure judicial process in which its resources often outmatched by financial firms that are "too big to fail." Following this strategy, it is relatively easy to claim that the settlements are serving the public interest since they ensure "positive results" by "penalizing" firms which are allegedly involved in wrongdoing and by recovering some illgotten monies they have made ${ }^{35}$.

\footnotetext{
35 Em tradução livre: "Seguindo esta orientação, a SEC assegura multas de milhões de dólares de empresas que adquiriram bilhões por meio de práticas assumidamente ilícitas. Os acertos, que incluem rotineiramente uma cláusula "nem admitir nem negar" permitem que a agência receba as multas sem arriscar um processo judicial incerto, no qual seus recursos frequentemente são superados por empresas financeiras que são "grandes demais para errar". Seguindo essa estratégia, é relativamente fácil dizer que os acertos estão servindo ao interesse público, uma vez que garantem "resultados positivos" por "penalizar" as empresas que estão supostamente envolvidos em irregularidades e recuperando algumas verbas ilícitas que adquiriram" SCHICOR, David. Financial Misrepresentation and fraudulent manipulation: SEC Settlements with Wall Street Firms in the Wake of the Economic Meltdown, p. 282.
} 
DIVAN, Gabriel Antinolfi. Revisitando a esquerda punitiva: relações sociais, poder e agenda atual da criminologia crítica. Revista Eletrônica Direito e Política, Programa de Pós-Graduação Stricto Sensu em Ciência Jurídica da UNIVALI, Itajaí, v.14, n.1, 10 quadrimestre de 2019. Disponível em: www.univali.br/direitoepolitica - ISSN 1980-7791

Bradshaw $^{36}$, na mesma linha, igualmente expõe outra face alarmante da questão criminal-dourada que é a total e completa complacência e falta de diligência (e/ou capacidade) dos poderes públicos na correta fiscalização e na (quando há o caso) devida criminalização de megacorporações em questões de desastres ambientais.

A explosão da unidade/plataforma petrolífera Deepwater Horizon (o nome parece profético ante o caso verificado) e do vazamento de gigantescas quantias de óleo no Golfo do México, em 2010, é alvo de um incisivo ensaio onde a pesquisadora coloca em xeque alguns paradoxos da dita monolítica hipossuficiência que, em relação a algumas categorias de investigados ou réus é conceito desconhecido aqui, em relação às (sempre) "too bigs" operadoras Transocean, contratada em leasing pela $B P-$ British Petroleum:

During the response, $\mathrm{BP}$, Transocean and the federal government attempted to suppress and control images and information surrounding the spill. Immediately following the explosion of the Deepwater Horizon drilling rig, lawyers interrogated and coerced the surviving crewmembers into signing waivers and required them to take drug tests upon returning to shore. On the evening of the explosion and throughout the following day, Transocean imposed a communications blackout to prevent the spread of information about the accident. Across the Gulf of Mexico, crews on offshore rigs were prohibited from using the telephone or Internet to contact friends and family. When the news finally made its way to land, the Coast Guard provided the few carefully controlled images of the Deepwater Horizon engulfed in flames to the public. This close control of information and images surrounding the spill by government and corporate officials established a trend that persisted for the duration of the response ${ }^{37}$

36 BRADSHAW, Elizabeth A. Blacking out the Gulf: State-Corporate Environmental Crime and the Response to the 2010 BP Oil Spill. In: BARAK, Gregg (Org.) The Routledge International Handbook of the Crimes of the Powerful. New York: Routledge, 2015, p. 362-372.

37 Em tradução livre: "Como resposta, a BP, a Transocean e do governo federal tentaram suprimir e controlar imagens e informações do derramamento. Imediatamente após a explosão da plataforma de perfuração Deepwater Horizon, advogados interrogaram e forçaram os tripulantes sobreviventes em acordos de confidencialidade e exigiam que eles fizessem testes de drogas ao voltar para a costa. $\mathrm{Na}$ noite da explosão e durante todo o dia seguinte, a Transocean impôs um bloqueio de comunicações para evitar a disseminação de informações sobre o acidente. Do outro lado do Golfo do México, as tripulações das plataformas offshore foram proibidas de usar o telefone ou Internet para contatar amigos e familiares. Quando a notícia finalmente chegou em terra, a Guarda Costeira providenciou apenas poucas imagens cuidadosamente controladas da Deepwater Horizon em chamas para o público. Este controle rigoroso de informações e imagens que cercam o derramamento, pelo 
DIVAN, Gabriel Antinolfi. Revisitando a esquerda punitiva: relações sociais, poder e agenda atual da criminologia crítica. Revista Eletrônica Direito e Política, Programa de Pós-Graduação Stricto Sensu em Ciência Jurídica da UNIVALI, Itajaí, v.14, n.1, 10 quadrimestre de 2019. Disponível em: www.univali.br/direitoepolitica - ISSN 1980-7791

Além da comprovação de que as empresas responsáveis tinham curioso acesso franqueado à opção de acordos extrajudiciais para impedir e ou driblar possibilidades probatórias do cometimento de dolo ou negligências no episódio, juntamente com agentes fiscalizadores governamentais e com uma inexplicável ajuda ou facilitação da Guarda Costeira do estado da Louisiana, elas mantinham a área do desastre em uma espécie de restrição física para tirar dos olhos do grande público o quanto fosse possível a dantesca consequência perceptível nas águas da costa, a olho nu. Além, é claro, de tentar maquiar o vazamento com um produto igualmente poluente a ser sorrateiramente despejado para dispersar as moléculas das línguas negras no oceano, em níveis de apenas aumentar o teor catastrófico do evento para o ecossistema local:

As the oil made landfall the federal government coordinated with BP to prevent officials, media and citizens from viewing the effects of the spill. In an effort to reduce the visibility of oil, BP applied almost two million gallons of toxic chemical dispersants with oversight from the Environmental Protection Agency and the Coast Guard. Moreover, the Coast Guard implemented a 65-foot "safety zone" around all cleanup operations, equipment and animals, making it nearly impossible for media to document the spill. Similarly, the Federal Aviation Administration also issued restrictions for media flights, prohibiting them from flying below 3,000 feet over segments of the Gulf of Mexico and the Louisiana shoreline. As a result, numerous reports quickly surfaced of journalists and photographers being denied access to the Gulf by $\mathrm{BP}$, the Coast Guard, local and state law enforcement and private security. In addition to suppressing images, BP intentionally altered official images of the spill to make the company appear more active than it was. Taken together, these actions constitute a coordinated statecorporate effort to conceal the environmental crimes unfolding in the Gulf of Mexico 38

governo e funcionários corporativos, estabeleceu uma tendência que persistiu ao longo dos pronunciamentos". BRADSHAW, Elizabeth A. Blacking out the Gulf: State-Corporate Environmental Crime and the Response to the 2010 BP Oil Spill, p. 363.

38 Em tradução livre: "Assim que o óleo atingiu a costa, o governo federal, coordenado com a BP, preveniu que funcionários, mídia e cidadãos vissem os efeitos do derramamento. Em um esforço para reduzir a visibilidade do petróleo, a BP aplicou quase dois milhões de litros de dispersantes químicos tóxicos com a supervisão da Agência de Proteção Ambiental e da Guarda Costeira. Além disso, a Guarda Costeira implementou uma zona de segurança de aproximadamente 65 pés em torno 
DIVAN, Gabriel Antinolfi. Revisitando a esquerda punitiva: relações sociais, poder e agenda atual da criminologia crítica. Revista Eletrônica Direito e Política, Programa de Pós-Graduação Stricto Sensu em Ciência Jurídica da UNIVALI, Itajaí, v.14, n.1, 10 quadrimestre de 2019. Disponível em: www.univali.br/direitoepolitica - ISSN 1980-7791

Seria uma ingenuidade (agora trocada de lado) ou uma desfaçatez crer, nos dias de hoje, que podemos utilizar a mesma base de argumentos jurídicos e plataforma de direitos políticos, in abstracto, para equiparar situações da criminalidade cotidiana que assola as camadas economicamente empobrecidas e aquelas que envolvem gestores e players do grande capital. Como resgata Cirino dos Santos ${ }^{39}$, a variável fundamental da criminalização secundária parece crua e diretamente a posição social do ator criminoso, e em muitas vezes passa ao largo da gravidade do delito, sua adequação típica e outros fatores técnicos.

Uma pavorosa mescla de exceção, barreiras circunstanciais (por vezes literais) e (no campo jurídico) total efetividade do conjunto de direitos e garantias liberaisburguesas está sempre a serviço, em plenitude, de poder ser usufruída por alguns tipos de proto-imputáveis penalmente. Enquanto que está, do mesmo modo, a uma distância inalcançável de ser miseramente cogitada por outros.

A insistência com o discurso de que a defesa de garantias é universal (no sentido de um universalismo moderno) pode ser repleta de intenções verdadeiramente democráticas, mas é impossível seguir discorrendo em tese sobre um reflexo concreto dessa linha argumentativa: se procura - não raro - pugnar pelo respeito às garantias liberal-burguesas em matéria jurídico-penal para, ideologicamente, minimizar os efeitos da sanha punitiva frente aos menos protegidos (verdadeiros hipossuficiente). No entanto, a distância refletida nos estamentos e classes (em luta) faz com que um triste binômio em relação a esses seja verificado: em duas pontas da tabela, o aparato punitivo os atinge sem que seja tão longo ou tão intenso para respingar na camada dourada - do mesmo modo que o discurso das garantias visa proteger a camada hipossuficiente, mas raramente tem força para

de todos equipamentos de operação de limpeza e animais, tornando quase impossível para a mídia para documentar o derramamento. Da mesma forma, a Administração Federal de Aviação também emitiu restrições para voos da mídia, proibindo-os de voar abaixo de 3.000 pés sobre segmentos do Golfo do México e da costa da Louisiana. Como resultado, numerosos relatórios rapidamente vieram à tona, sobre jornalistas e fotógrafos que tiveram negado o acesso ao Golfo pela BP, a Guarda Costeira, forças da lei locais e segurança privada. Além de imagens suprimidas, a BP alterou intencionalmente imagens oficiais do derramamento para fazer a empresa parecer mais ativa do que havia sido. Tomadas em conjunto, essas ações constituem um esforço estatal-empresarial coordenado para esconder os crimes ambientais ocorridos no Golfo do México". BRADSHAW, Elizabeth A. Blacking out the Gulf: State-Corporate Environmental Crime and the Response to the 2010 BP Oil Spill, p. 364.

39 CIRINO DOS SANTOS, Juarez. Direito penal. Parte Geral, p. 12. 
DIVAN, Gabriel Antinolfi. Revisitando a esquerda punitiva: relações sociais, poder e agenda atual da criminologia crítica. Revista Eletrônica Direito e Política, Programa de Pós-Graduação Stricto Sensu em Ciência Jurídica da UNIVALI, Itajaí, v.14, n.1, $1^{\circ}$ quadrimestre de 2019. Disponível em: www.univali.br/direitoepolitica - ISSN 1980-7791

não se exaurir ao atravessar o território hipersuficiente. Em tom mais direto: a defesa de garantias político-jurídicas tipicamente liberais e/ou o raio de direitos constitucionais fundamentais está, assim como a pior face do poder punitivo, disponível com o sinal amplificado apenas para alguns. Seria, inclusive, possível dizer que, se a hipocrisia que enaltece magistrados e figuras da persecução penal como titãs moralistas é patente e abjeta, também cabe a crítica a quem queira fazer valer a tese que o respingo altamente ocasional do sistema penal em algumas categorias privilegiadas de pessoas é uma espécie de vitimização ou martírio.

Lembrando que para o caso ad-hoc de alguns, até mesmo as instalações prisionais (que todo o dia se transmutam mais e mais em masmorras desumanas destinadas à clientela típica cujos direitos básicos são emudecidos) procuram adaptações, em uma realidade retorcida que beira o inexplicável.

Até o discurso raivoso da efetividade punitivista parece se tranquilizar diante de certos fatores: a seletividade penal e os ranços do sistema atuam para mais direções do que se supõe inicialmente.

\section{A ESQUERDA PUNITIVA VISTA COMO DISCURSO ANTI-GARANTISTA}

Sumariamente: um pleito de equilíbrio não necessariamente pode ser vilipendiado como ode à repressão.

Verifica-se no seio da sociedade brasileira e no jogo político-partidário (especialmente) uma polarização cada vez mais aguda que chega a perverter o adágio da condição de política enquanto guerra por outros meios (ou ironicamente vice-versa): no balanço situacional, inimigos de outrora viram aliados instantâneos em um costume que também é teórico-ideológico. Aí vem em boa hora a denúncia de $\operatorname{Karam}^{40}$ : a esquerda punitiva tem como característica uma adesão a todos os alinhamentos e mecanismos do establishment, ao passo que isso seja conveniente ou não. Especialmente no reforço dos argumentos justificadores, antigas agências e organismos propagadores das hostes adversárias rapidamente ganham

40 KARAM, Maria Lúcia. A esquerda punitiva, p. 83. 
DIVAN, Gabriel Antinolfi. Revisitando a esquerda punitiva: relações sociais, poder e agenda atual da criminologia crítica. Revista Eletrônica Direito e Política, Programa de Pós-Graduação Stricto Sensu em Ciência Jurídica da UNIVALI, Itajaí, v.14, n.1, 10 quadrimestre de 2019. Disponível em: www.univali.br/direitoepolitica - ISSN 1980-7791

credibilidade - sobretudo a imprensa - quando legam o mínimo de apoio, ainda que mediato, à causa (seja ela qual for).

Se só cabe acompanhar a autora no brado contra essa hipocrisia gritante (bastante verificada no Brasil das timelines de redes sociais onde meios de comunicação, opiniões, verbetes, memes e os próprios pensadores são interditados ou compartilhados conforme a maré), é preciso dizer também que isso não pode se referir a toda e qualquer práxis de esquerda, nem a todo e qualquer pensador da criminologia que procura dar foco ao borrão ideológico aqui identificado. É possível tachar pejorativamente os (muitos) arautos desse tipo de combate, no mesmo passo que é necessário reconhecer que não se pode generalizar, do mesmo modo.

É perfeitamente possível a defesa de um ideário jurídico-processual constitucionalgarantista, que, estando alinhado com conceitos e ditames de uma criminologia essencialmente crítica (na linha de um conjunto de aparelhagem ${ }^{41}$ ), questione tanto os problemas de ordem processual-penal e seu grau de ratio interventiva quanto aqueles criminológicos relativos à atuação "padrão" do sistema. Inclusive, a repulsa a um garantismo puramente utilitarista e que pode ser cooptado facilmente dos pontos de vista teórico e prático (na esteira do que alertam Batista ${ }^{42}$ e Devos ${ }^{43}$ ), é possível de ser feita com a defesa de um ensino e um compromisso militante de modelos teóricos e políticos de processo penal inundados de conteúdo criminológico 44 .

As discussões em torno de estratégias políticas, bem como aquelas que gravitam sobre posicionamentos e conceitos jurídicos passíveis de amplitude de

\footnotetext{
${ }^{41}$ DIVAN, Gabriel Antinolfi. Processo penal e política criminal: Uma reconfiguração da justa causa para a ação penal. Porto Alegre: Elegantia Juris, 2015, p. 96-129.

42 BATISTA, Vera Malaguti. Introdução crítica à criminologia brasileira, p. 104.

43 DEVOS, Bryan Alves. (In)segurança, cidadania e poder punitivo: Crítica ao utilitarismo penal reformado e readequação da missão do Direito Penal ao marco de um realismo jurídico-penal marginal. Dissertação (Mestrado em Direito e Justiça Social). Faculdade de Direito. Fundação Universidade Federal de Rio Grande-RS. Rio Grande: FURG, 2016, especialmente p. 164202.

${ }^{44}$ Cf. DIVAN, Gabriel Antinolfi. Justa causa para a ação penal e suas possibilidades criminológicas criminologia(s) no processo penal (hipótese preliminar). REDES - Revista Eletrônica Direito e Sociedade. Canoas: Volume 3, n. 1, Maio/2015. Disponível em: https://revistas.unilasalle.edu.br/index.php/redes/article/view/2130 Acesso em 14 de Novembro de 2017.
} 
DIVAN, Gabriel Antinolfi. Revisitando a esquerda punitiva: relações sociais, poder e agenda atual da criminologia crítica. Revista Eletrônica Direito e Política, Programa de Pós-Graduação Stricto Sensu em Ciência Jurídica da UNIVALI, Itajaí, v.14, n.1, 10 quadrimestre de 2019. Disponível em: www.univali.br/direitoepolitica - ISSN 1980-7791

interpretação, não podem ser eivadas de uma retórica que consista apenas em associar o lado oposto a premissas de antemão inaceitáveis em uma base comum arbitrada. Mormente quando as premissas são igualmente inaceitáveis, de forma pré-estabelecida e explícita e mormente quando essa base comum não é outra senão o universo de garantias, direitos e valores fundamentais e democráticos que sustentam o espectro político e jurídico pátrio.

Sem negar que parte do ideário punitivista (de esquerda, direita ou centro) se vale da estratégia de dicotomização de ares metafísicos para instaurar um clima de disputa entre bem e mal, vivificado em polarizações como "cidadão de bem" e "criminoso" ou "a sociedade" (sic.) e "a bandidagem", etc., a eleição arbitrária de lados ou times em contenda é aparelho discursivo - e nada mais - na maioria dos casos.

Assim, apesar da ressalva feita por $\operatorname{Karam}^{45}$, não pode ser toda e qualquer demanda criminalizadora ou que venha assentir que uma imputação feita em trâmites minimamente legais e coerentes com o universo legal e procedimental do sistema jurídico-penal seja um cheque em branco para que se passe indiscriminadamente à estigmatização proposital dos(as) suspeitos(as), acusados(as) e condenados(as). Sabe-se que a estigmatização inerente às próprias mazelas do sistema jurídico-penal é perversa e de cunho rápido e automatizado. Sabe-se (e não é igualmente preciso elucubrar muito para) que a opinião pública média atrelada ao descompromisso moral de uma verdadeira indústria do medo fomentada em muito pela mídia de massas colabora para o quesito de forma exponencial (como recorda Young ${ }^{46}$ ).

Contudo, não há como unificar, simplesmente, a ideia de que uma vontade de responsabilização e/ou uma cobrança quanto à atividade sistemática em todo e qualquer caso penal verificado se associe à sanha inquisidora de empresários morais, "homens médios" e similares.

\footnotetext{
45 KARAM, Maria Lúcia. A esquerda punitiva, p. 88.

46 YOUNG, Jock. El fracasso de la criminologia: la necesidad de un realismo radical, p. 33.
} 
DIVAN, Gabriel Antinolfi. Revisitando a esquerda punitiva: relações sociais, poder e agenda atual da criminologia crítica. Revista Eletrônica Direito e Política, Programa de Pós-Graduação Stricto Sensu em Ciência Jurídica da UNIVALI, Itajaí, v.14, n.1, 10 quadrimestre de 2019. Disponível em: www.univali.br/direitoepolitica - ISSN 1980-7791

Ocorre, sim, o fato de que não há sentimento confortável em se militar em um âmbito de defesa de garantias e de direitos basilares (que se somam à militância contra o binômio legitimação-expansão do poder punitivo, em várias frentes) visando fortalecer uma base e uma parcela dos atingidos pela face mais cruel do sistema e perceber que se termina sempre blindando os mesmos de sempre. Além disso: tecendo argumentos que só ocasionam que os mesmos blindados de sempre assim o sigam, colaborando para a imutabilidade e falta de transitoriedade do panorama.

Poder-se-ia dizer (ou repetir) a falácia da contaminação, que acusa os discursos não essencialmente abolicionistas de terminarem por gerar apenas mais combustível para o funcionamento da engrenagem com os rumos corriqueiros cai por terra. Tristemente, a punitividade em grau máximo que aflige a underclass não macula a permissividade da qual os dourados usufruem, bem como o reconhecimento das garantias (ou da não excepcionalidade enquanto regra) que é típica dos "dourados" não beneficia os demais, em geral.

Antes que se diga que se estaria procurando igualar ambos no flagelo - ao invés de buscar universalidade das garantias para tentar equiparar utilitariamente as benesses, cabe a reprise do aviso em forma de pergunta ou ponderação: até lá (a metáfora do horizonte utópico que caminha juntamente ao andar do caminhante que o observa), a perversidade e a permissividade do(s) desequilíbrio(s) deveria ser, em hipótese, tolerada, ou aceita passivamente, portanto. Tem-se algo de descalabro, inegavelmente.

\section{CONSIDERAÇÕES FINAIS}

Parece difícil de ser superada a constatação base feita por Karam ${ }^{47}$ sem que se coloque em questão ou em estado de paralisia o próprio teor do que aqui é apresentado: a seletividade, o elitismo - bem como a misoginia, o machismo, o racismo e toda uma gama de preconceitos que escopos preconceituosos - é intrínseca, original e constitutiva do sistema penal como o conhecemos no modo

\footnotetext{
47 KARAM, Maria Lúcia. A esquerda punitiva, p. 83.
} 
DIVAN, Gabriel Antinolfi. Revisitando a esquerda punitiva: relações sociais, poder e agenda atual da criminologia crítica. Revista Eletrônica Direito e Política, Programa de Pós-Graduação Stricto Sensu em Ciência Jurídica da UNIVALI, Itajaí, v.14, n.1, $1^{\circ}$ quadrimestre de 2019. Disponível em: www.univali.br/direitoepolitica - ISSN 1980-7791

de produção capitalista, e mais visível nos reflexos e desdobramentos neoliberais do mesmo ${ }^{48}$.

Zaffaroni ${ }^{49}$ há muito, foi bastante incisivo, na constatação, que não se altera infelizmente - ante o tempo transcurso:

(...) torna-se óbvio que o sistema penal está estruturalmente montado para que a legalidade processual não opere, e, sim, para que exerça seu poder com altíssimo grau de arbitrariedade seletiva dirigida, naturalmente aos setores vulneráveis.

Porém, se não se conseguiria virar - simplesmente - as baterias e alças de mira do sistema para locais onde ele não foi essencialmente programado para agir pela lógica reinante que o sustenta, é preciso, assim como em relação a esses efeitos também intrinsicamente ligados à sociedade capitalista e patriarcal, um trabalho de desconstrução. Não se pode simplesmente pugnar uma tolerância com o descalabro disfuncional da maquinaria punitiva como se essa fosse um ganho (como se a disfuncionalidade fosse boa no instante em que, ao fim e ao cabo, pune a menos, em relação a algumas pessoas).

Ademais, é preciso que evoluam e se (auto) critiquem constantemente as conclusões sobre a eficácia (mesmo que simbólica) do direito penal em alguns casos como aqueles de minorias que são barradas de pleitear implemento penal de suas causas, como se tivessem deslegitimadas de fazer isso ante a tese da ingenuidade que militaria a favor do establishment (penal) e assim, contra o próprio movimento. Mais uma vez, age-se como se as minorias merecessem tutela ou algum tipo de direcionamento para militar corretamente e como se perdessem seu caráter de luta "genuína" de minoria ao querer se aliar de forma acéfala ao pan-penalismo.

\footnotetext{
${ }^{48}$ BATISTA, Vera Malaguti. Introdução crítica à criminologia brasileira, p. 99-111

49 ZAFFARONI, Eugenio Raúl. Em busca das penas perdidas: A perda de legitimidade do sistema penal. 4a edição. Tradução de Vania Romano Pedrosa. Rio de Janeiro: Revan, 1999, p. 27.
} 
DIVAN, Gabriel Antinolfi. Revisitando a esquerda punitiva: relações sociais, poder e agenda atual da criminologia crítica. Revista Eletrônica Direito e Política, Programa de Pós-Graduação Stricto Sensu em Ciência Jurídica da UNIVALI, Itajaí, v.14, n.1, $1^{\circ}$ quadrimestre de 2019. Disponível em: www.univali.br/direitoepolitica - ISSN 1980-7791

Isso ocorre, por exemplo, com a pauta de defesa dos direitos ligados à homoafetividade, que, não raramente, se vê necessariamente combatendo discursos heteronormativos de ódio de caráter nitidamente criminoso, mas disfarçados de "livre expressão" tal e qual alerta Santos ${ }^{50}$. Não se pode acusar o pleito criminalizante nesses casos de pura e simplesmente querer inflar a malha punitiva e aumentar a própria incidência de padrões que em tese lhe contrariam em última análise. Isso seria barrar qualquer alternativa alegando-a como genericamente pro-establishment(s). A defesa da criminalização ou da tutela penal sem inovação legislativa, aqui, são buscas nítidas por equilíbrio e igualdade (conforme expõe Masiero ${ }^{51}$ ) e não podem ser sempre diminuídas enquanto tolas ou úteis ao reacionarismo (conquanto mostram conteúdo frontalmente assumido em defesa de direitos humanos e fundamentais).

Sob outro e importantíssimo prisma, apenas naquilo que Prando ${ }^{52}$ denomina de "terceira onda" dos estudos críticos criminológicos no Brasil (e na América Latina em geral), a tematização de estudos relativos à raça deixou de ser abordada de forma tangencial ou de ganhar uma simpatia longínqua. Questões a isso relativas ganharam não o relevo de uma importância etérea, mas a necessidade premente, inclusive, de se pensarem gramáticas e referenciais exclusivos - diante do que a própria autora comenta que é uma visão da questão racial a partir de um componente inafastável de branquidade.

Trabalhos como os de Flauzina ${ }^{53}$ trazem a dose de realidade urgente e aterradora daquilo que se constata como um "confinamento racial acadêmico" dos estudos

50 Cf. SANTOS, Carolinne Nhoato dos. Discurso do ódio: o limite à liberdade de expressão e a busca pelo movimento LGBT pelo direito a não discriminação. In: OLIVIERO, Maurizio. Direito constitucional comparado e neoconstitucionalismo. Volume 2. Perugia: Universitá Degli Studi di Perugia/Univali, 2016, p. 50-67.

51 MASIERO, Clara Moura. O movimento LGBT e a homofobia: Novas perspectivas de políticas sociais e criminais. Porto Alegre: Criação Humana, 2014, p. 124-126.

52 PRANDO, Camila Cardoso de Mello. A criminologia crítica no Brasil e os estudos críticos sobre branquidade. Direito \& Práxis. Rio de Janeiro, Volume 9, n. 1, 2018. P. 70-84. Disponível em: http://www.e-publicacoes.uerj.br/index.php/revistaceaju/article/view/25378 Acesso em 14 de Julho de 2018.

53 Cf. FlaUZinA, Ana Luiza Pinheiro. Corpo Negro caído no chão: o sistema penal e o projeto genocida do Estado brasileiro. Rio de Janeiro: Contraponto, 2008. 
DIVAN, Gabriel Antinolfi. Revisitando a esquerda punitiva: relações sociais, poder e agenda atual da criminologia crítica. Revista Eletrônica Direito e Política, Programa de Pós-Graduação Stricto Sensu em Ciência Jurídica da UNIVALI, Itajaí, v.14, n.1, $1^{\circ}$ quadrimestre de 2019. Disponível em: www.univali.br/direitoepolitica - ISSN 1980-7791

criminológicos pátrios ${ }^{54}$ - e com isso se reafirmam como necessários certos âmbitos de repensar a coligação excludente da vanguarda crítica com a aceitação exclusiva de legitimidade das teses se elas estiverem unidas a um ideal dito abolicionista, que não assume nem admite questões, modulações e alterações de rota diante da facticidade. Há um brado crítico de recusa ao efeito nefasto do controle e do poder que, contudo, insiste em se apresentar como o mesmo e imutável brado, fraquejando em dúplice viés: um, quando não admite (contraditoriamente com a própria força que o anima) qualquer nuance diferenciada ou transgressiva de sua esteira-base; dois, quando (ainda que de outro modo) segue fetichizando, emudecendo e compartimentalizando todo e qualquer de seus objetos de estudo e ideais de defesa.

Assim, parece que é necessário que sejam também considerados como pauta genuína de uma criminologia crítica a necessidade de discussão quanto às distorções preconceituosas do sistema punitivo, sem que se rotule como falsárias ou intrusas (ou ingênuas) aquelas que terminam por se distanciar de uma inconsequência abolicionista-idealista.

Seria viável abrir mais uma miríade, composta por um sem número de objeções temáticas, mas apenas com breves menções (que jamais farão, em um ligeiro espaço, jus ao vulto que têm, e merecem ter, pautas como o trato jurídico-penal das questões de gênero, orientação sexual e - especialmente em nosso país raciais) é possível deixar inscrito o fato de que uma abordagem genuinamente crítica não pode (ou não pode apenas e repetidamente, às raias da segunda década do século XXI) ser pautada exclusivamente por um tom de negação ou recusa intransigente. A questão racial e a possibilidade de que se lute para uma valorização de bens jurídicos atinentes no campo penal é um excelente exemplo: ao invés de se configurar como bandeira de conscientização crítica, usualmente

\footnotetext{
${ }^{54}$ Cf. CALAZANS, Márcia Esteves de; PIZA, Evandro; PRANDO, Camila; CAPPI, Ricardo. Criminologia Crítica e Questão Racial. Cadernos do CEAS. Salvador: UCSal. N. 238, Especial Setembro 2016. p. 450-463 Disponível em: https://cadernosdoceas.ucsal.br/index.php/cadernosdoceas/article/view/280/216 Acesso em 09 de Maio de 2017.
} 
DIVAN, Gabriel Antinolfi. Revisitando a esquerda punitiva: relações sociais, poder e agenda atual da criminologia crítica. Revista Eletrônica Direito e Política, Programa de Pós-Graduação Stricto Sensu em Ciência Jurídica da UNIVALI, Itajaí, v.14, n.1, $1^{\circ}$ quadrimestre de 2019. Disponível em: www.univali.br/direitoepolitica - ISSN 1980-7791

mal disfarça o sentimento de se revestir de um novo (ou contrafeito) tipo de interdição. Mais um, em relação à negritude, por exemplo.

Esse dogma da recusa de mirada abolicionista pode muito bem ser a tônica motriz que faz de uma postura crítica um discurso de não-normalização e não apaziguamento, tão tipicamente distinto daqueles de vertentes adesistas ou nefelibatas. Porém a crítica não pode abrir mão da auto crítica condizente e de lutar em um sistema que preveja avanços e recuos, ambos estratégicos.

Como um pequeno agrupado de premissas ou ideias finais, poder-se-ia expor:

a) Não é possível identificar exclusivamente uma corrente de crítica verdadeira ou sincera para a questão da (des)legitimação do poder punitivo, não sendo passível de rotular pejorativamente como "esquerda punitiva" todos aqueles que - conforme os motivos expostos - aceitam ou mesmo eventualmente defendem uma (necessariamente minimalista e racional) atuação penal;

b) Em realidade, colocando foco na questão suscitada como mote ou guia de análise ora aventada, o discurso que enfrenta as mazelas de uma esquerda punitiva tem sido - lamentavelmente - menos um brado contra a expansão punitiva e contra os efeitos de roldão que se acostam à tentativa (ingênua) de uso (benéfico) do braço punitivo, e mais uma espécie de refúgio ou ferrolho argumentativo para que qualquer abalo genuíno, colateral ou proposital que algum tipo de criminalização possa causar nos establishments (englobado também o establishment da crítica jurídico-penal vanguardista) seja neutralizado. É um discurso que nasce da necessidade de proteção das pautas críticas e humanistas contra a sedução do uso do poder punitivo, e que, muitas vezes, acaba ele próprio seduzido para impedir qualquer agenda ou análise diversa, favorecendo, assim, em última análise, os interesses opostos aos que gostaria de expor e combater;

c) Se o pecado (ou um dos pecados) de teorias punitivistas (que nessa quadra histórica se aglutinam em tornos de preceitos higienistas de lei e ordem) é o simplismo cartesiano de rotulações, essa falha (simplismo) a episteme da criminologia crítica (pós)moderna não pode ter - eis que forjada no pensamento complexo; 
DIVAN, Gabriel Antinolfi. Revisitando a esquerda punitiva: relações sociais, poder e agenda atual da criminologia crítica. Revista Eletrônica Direito e Política, Programa de Pós-Graduação Stricto Sensu em Ciência Jurídica da UNIVALI, Itajaí, v.14, n.1, $1^{\circ}$ quadrimestre de 2019. Disponível em: www.univali.br/direitoepolitica - ISSN 1980-7791

d) Talvez uma possibilidade bastante especulativa de proposta crível para o fim ou a verdadeira minimização do espectro punitivo na sociedade capitalista neoliberal esteja justamente nos questionamentos a partir do momento em que o sistema deixar de servir de cordão de isolamento para as manutenções de status quo triviais. Deixar ele como está, funcionando no auge do desequilíbrio, não parece estar ajudando na empresa;

e) A deslegitimação parcelada do sistema penal e a certeza de intensidade máxima desigual com a qual ele age parecem muito mais fatores propulsores da continuidade perene da injustiça concreta do que pequenas vitórias parceladas em virtude de o mal propagado pelo sistema não ser a todos estendido.

É preciso que se assumam certas posturas limítrofes para que se possa render uma sincera homenagem e se renove o compromisso que tantos pensadores e pensadoras da crítica ao sistema jurídico-penal brasileiro fazem ecoar em Karam e em tantos demais, para quem nunca faltou coragem de remar no sentido contrário ao de algumas correntezas.

\section{REFERÊNCIAS DAS FONTES CITADAS}

ANITUA, Gabriel Ignácio. Historias de los pensamientos criminológicos. Buenos Aires: Del Porto, 2005.

BARAK, Gregg. Limiting Financial Capital and Regulatory Control as Non-penal Alternatives to Wall Street Looting and High-Risk Securities Frauds. In: BARAK, Gregg. The Routledge International Handbook of the Crimes of the Powerful. New York: Routledge, 2015, p. 525-536.

BRADSHAW, Elizabeth A. Blacking out the Gulf: State-Corporate Environmental Crime and the Response to the 2010 BP Oil Spill. In: BARAK, Gregg (Org.) The Routledge International Handbook of the Crimes of the Powerful. New York: Routledge, 2015, p. 362-372.

BATISTA, Vera Malaguti. Introdução crítica à criminologia brasileira. $1^{a}$ reimpressão. Rio de Janeiro: Revan, 2014.

CALAZANS, Márcia Esteves de; PIZA, Evandro; PRANDO, Camila; CAPPI, Ricardo. Criminologia Crítica e Questão Racial. Cadernos do CEAS. Salvador: UCSal. N. 
DIVAN, Gabriel Antinolfi. Revisitando a esquerda punitiva: relações sociais, poder e agenda atual da criminologia crítica. Revista Eletrônica Direito e Política, Programa de Pós-Graduação Stricto Sensu em Ciência Jurídica da UNIVALI, Itajaí, v.14, n.1, $1^{\circ}$ quadrimestre de 2019. Disponível em: www.univali.br/direitoepolitica - ISSN 1980-7791

238, Especial Setembro 2016. p. 450-463 Disponível em: https://cadernosdoceas.ucsal.br/index.php/cadernosdoceas/article/view/280/216 Acesso em 09 de Maio de 2017.

CARVALHO, Salo de. Teoria Agnóstica da Pena: entre os supérfluos fins e a limitação do poder punitivo In. CARVALHO, Salo de. Crítica à Execução Penal. $2^{a}$ edição. Rio de Janeiro: Lumen Juris, 2007, p. 3-28.

CIRINO DOS SANTOS, Juarez. A criminologia radical. 2a edição. Rio de Janeiro: Lumen Juris/ICPC, 2006.

. Direito Penal. Parte Geral. 2a edição. Revista e ampliada. Rio de Janeiro: Lumen Juris/ICPC, 2007.

DEVOS, Bryan Alves. (In)segurança, cidadania e poder punitivo: Crítica ao utilitarismo penal reformado e readequação da missão do Direito Penal ao marco de um realismo jurídico-penal marginal. Dissertação (Mestrado em Direito e Justiça Social). Faculdade de Direito. Fundação Universidade Federal de Rio Grande-RS. Rio Grande: FURG, 2016.

DIVAN, Gabriel Antinolfi. CASTAMANN, Eduardo Tedesco. Realismo crítico, política criminal e dogmática: o papel ativo do discurso criminológico na inovação legislativa e doutrinária. Revista de Criminologias e Políticas Criminais. Maranhão: CONPEDI, volume 3, n. 2, p. 33-48, Julho/Dezembro de 2017. Disponível em: http://indexlaw.org/index.php/revistacpc/article/view/2368/pdf Acesso em 02 de Fevereiro de 2018.

DIVAN, Gabriel Antinolfi. Justa causa para a ação penal e suas possibilidades criminológicas - criminologia(s) no processo penal (hipótese preliminar). REDES - Revista Eletrônica Direito e Sociedade. Canoas: Volume 3, n. 1, Maio/2015. Disponível em: https://revistas.unilasalle.edu.br/index.php/redes/article/view/2130 Acesso em 14 de Novembro de 2017.

Processo penal e política criminal: Uma reconfiguração da justa causa para a ação penal. Porto Alegre: Elegantia Juris, 2015.

. Qual nossa única reivindicação? Representatividade e cruzamentos políticos para a construção de uma 'criminologia 2.0'. Panóptica. Vitória: FDV vol. 10, n. 2, p. 158-175, Julho/Dezembro, 2015.

DOLCINI, Emilio; MARINUCCI, Giorgio. Constituição e escolha de bens jurídicos. Tradução de José de Faria Costa. Revista Portuguesa de Ciência Criminal. Lisboa: Fascículo 2. Ano 4, p. 151-198, Abril/Junho, 1994.

FERRAJOLI, Luigi. Derecho y razón: Teoría del garantismo penal. Tradução de Perfecto Andres Ibáñez et alii. Madrid: Trotta, 1995. 
DIVAN, Gabriel Antinolfi. Revisitando a esquerda punitiva: relações sociais, poder e agenda atual da criminologia crítica. Revista Eletrônica Direito e Política, Programa de Pós-Graduação Stricto Sensu em Ciência Jurídica da UNIVALI, Itajaí, v.14, n.1, $1^{\circ}$ quadrimestre de 2019. Disponível em: www.univali.br/direitoepolitica - ISSN 1980-7791

FERREIRA, Carolina Costa. Discursos do Sistema Penal: A seletividade no julgamento dos crimes de furto, roubo e peculato nos tribunais regionais federais do Brasil. Curitiba: Editora CRV, 2013.

FLAUZINA, Ana Luiza Pinheiro. Corpo Negro caído no chão: o sistema penal e o projeto genocida do Estado brasileiro. Rio de Janeiro: Contraponto, 2008.

FOUCAULT, Michel. Sobre a justiça popular. In: MACHADO, Roberto (org.). Microfísica do poder. 20. ed. Tradução de Roberto Machado. Rio de Janeiro: Graal, 2004.

KARAM, Maria Lúcia. A esquerda punitiva. Discursos Sediciosos: Crime, Direito e Sociedade. Rio de Janeiro: Relume Dumará/ICC. Ano 1, volume 1, p. 79-92, 10 semestre/1996.

LARRAURI, Elena. Criminología crítica: abolicionismo y garantismo. Revista de Estudos Criminais. Porto Alegre: Notadez/ITECRS/PUCRS Ano V, n. 20, p. 1128, Dezembro/2005.

España, 2000.

La Herencia de la Criminología Crítica. Madrid: Siglo Veintiuno de

MARX, Karl. Crítica ao Programa de Gotha. Tradução de Rubens Enderle. São Paulo, Boitempo, 2012.

MASIERO, Clara Moura. O movimento LGBT e a homofobia: Novas perspectivas de políticas sociais e criminais. Porto Alegre: Criação Humana, 2014.

MATTHEWS, Roger. Realist Criminology. London: Palgrave Macmillan, 2014.

NAVES, Márcio Bilharino. Marxismo e direito: Um estudo sobre Pachukanis. Tese (Doutorado em Filosofia). Instituto de Filosofia e Ciências Humanas. Universidade Estadual de Campinas. Capinas: Unicamp, 1996.

PACHUKANIS, Evguiéni B. Teoria geral do direito e marxismo. $1^{\text {a }}$ edição. Tradução de Paula Vaz de Almeida. São Paulo: Boitempo, 2017.

PINTO NETO, Moysés da Fontoura. Em defesa da esquerda punitiva. Rastros, n. 1. Revista Eletrônica. Desterro, out. 2012, p. 4. Disponível em: <http://culturaebarbarie.org/rastros/n1.html>. Acesso em: 03 de Abril de 2017.

PRANDO, Camila Cardoso de Mello. A criminologia crítica no Brasil e os estudos críticos sobre branquidade. Direito \& Práxis. Rio de Janeiro, Volume 9, n. 1, 2018. P. 70-84. Disponível em: http://www.epublicacoes.uerj.br/index.php/revistaceaju/article/view/25378 Acesso em 14 de Julho de 2018.

SANTOS, Carolinne Nhoato dos. Discurso do ódio: o limite à liberdade de expressão e a busca pelo movimento LGBT pelo direito a não discriminação. In: OLIVIERO, 
DIVAN, Gabriel Antinolfi. Revisitando a esquerda punitiva: relações sociais, poder e agenda atual da criminologia crítica. Revista Eletrônica Direito e Política, Programa de Pós-Graduação Stricto Sensu em Ciência Jurídica da UNIVALI, Itajaí, v.14, n.1, $1^{\circ}$ quadrimestre de 2019. Disponível em: www.univali.br/direitoepolitica - ISSN 1980-7791

Maurizio. Direito constitucional comparado e neoconstitucionalismo. Volume 2. Perugia: Universitá Degli Studi di Perugia/Univali, 2016, p. 50-67.

SHICOR, David. Financial Misrepresentation and fraudulent manipulation: SEC Settlements with Wall Street Firms in the Wake of the Economic Meltdown In. BARAK, Gregg (Org.) The Routledge International Handbook of the Crimes of the Powerful. New York: Routledge, 2015, p. 278-288.

YOUNG, Jock. El fracasso de la criminologia: la necesidad de un realismo radical In. HULSMAN, Louk; RECASENS I BRUNET, Amadeu; VAN SWAANINGEN, Rene; BERGALLI, Roberto; ZAFFARONI, Eugenio R.; CHRISTIE, Nils, YOUNG, Jock. Criminología crítica y control social: El poder punitivo del Estado. Tradução de Ramiro Sagarduy. Rosário: Editorial Juris, 1993, p. 7-42.

ZAFFARONI, Eugenio Raúl; ALAGIA, Alejandro; SLOKAR, Alejandro. Derecho penal: Parte general. 2a edição. Buenos Aires: EDIAR, 2002.

ZAFFARONI, Eugenio Raúl. Em busca das penas perdidas: A perda de legitimidade do sistema penal. $4^{a}$ edição. Tradução de Vania Romano Pedrosa. Rio de Janeiro: Revan, 1999.

RECEBIDO EM: 22/11/2018

APROVADO EM: 30/01/2019 